\title{
The Dorsoepicondylar Medial Muscle a Clinically Relevant Anatomical Variation
}

\author{
El Músculo Dorsoepicondylar Medial. Una Variación Anatómica Clínicamente Relevante
}

Emilio Farfán C.; Oscar Inzunza H.; Mark Echeverría M. \& Verónica Inostroza R.

FARFÁN, C. E.; INZUNZA, H. O.; ECHEVERRÍA, M. M. \& INOSTROZA, R. V. The dorsoepicondylar medial muscle, a clinically relevant anatomical variation. Int. J. Morphol., 37(2):600-605, 2019.

SUMMARY: Anatomical variations in the axillary region do not always appear in modern human anatomy texts, which leaves the risk of diagnostic and surgical errors by doctors unaware of these variations. This work presents an anatomical variation of muscular type in the axillary region that can potentially generate clinical manifestations or iatrogenic results during surgical procedures. Routine dissection of an upper limb in a male cadaver. An atypical muscle was found in the axillary region, located at the base of the right axilla, and conformed by three muscle fascicles that give rise to a common muscular belly. The three fascicles are joined at the base of the axilla, and form a thin flat muscle 120 $\mathrm{mm}$ long from this join to its tendon, with a cross-section diameter of $15 \mathrm{~mm}$ and a thickness of $2 \mathrm{~mm}$. The common belly of the muscle establishes a posterior relationship with the neurovascular elements of the axillary fossa and partially covers them. The tendon $150 \mathrm{~mm}$ in length originates at the level of the union of the upper and middle thirds of the arm and ends inserted in the medial epicondyle of the humerus, relating in its path with muscular and neurovascular elements of the arm. Being familiar with this variation enriches diagnostic and surgical abilities and reduces the possibility of iatrogenia in surgery of the axillary and brachial regions.

KEY WORDS: Dorsoepicondylar medial muscle; Anatomical variation; Clinical anatomy.

\section{INTRODUCTION}

While anatomical variations are common in the axillary region, not all has been described in modern human anatomy and surgical anatomy texts, raising the risk of severe injury during surgery procedure. Kutiyanawala et al. (1998) documented 100 axillary dissections in which they found 29 cases of anatomical variations that included vascular, nerve and muscular variations, which could be relevant during surgery of the axillary fossa, such as ligation of the axillary artery, excision of the axillary vein or resection of lymph nodes.

There have been numerous descriptions of muscular variations in the axillary region, in the axillary fossa or in the walls that form it, including Langer's axillary arch, which is a muscle-fascial arch that originates in the lateral edge of the latissimus dorsi muscle and passes in front of the axillary vessels and nerves to join the fascia of the coracobrachialis muscle (Ortiz et al., 2009; Standring, 2016). The panniculus carnosus is another muscular variant in the axillary fossa. It is a muscular-tendinous structure that extends from the base of the coracoid process, passing in front of the subscapular muscle and ends as an aponeurotic expansion in front of the latissimus dorsi muscle (Inzunza et al., 2008). A similar muscular structure was described by del Sol \& Olave (2005), the "levator muscle of the tendon of latissimus dorsi muscle", these fusiform fascicle extends from the coracoid process to the superior part of the tendon of the cited muscle. In relation to the anterior wall of the axillary, it has been described variations like the "third pectoral muscle", a supernumerary fascicle extending between the coracoid process and the crest of tubercle major of the humerus, towards the fascia of the pectoralis minor muscle; this muscle takes relation with the inferolateral edge of the pectoralis major muscle, following a parallel trajectory in a deeper plane (del Sol \& Vásquez, 2009). The "fourth pectoral muscle" is another very rare muscular variation located in the anterior wall of the axilla. It consists in a triangular muscle originating from the thoracic wall at the level of the sixth rib between the pectoralis major and the latissimus dorsi muscles, which follows an ascending path of about $10 \mathrm{~cm}$ and ends inserted into the inner side of the lower edge of the pectoralis major (Sawada et al., 1991). In addition, del Sol \& Vieira (1989) described the chondroepicondilar muscle, supernumerary fascicle of the 
pectoralis major muscle, that extends from the six and seventh costal cartilages and ascend with the muscle fibers and generates a long and thin tendon that extends from the anterior lip of the intertubercular groove to the medial epicondyle of the humerus.

Having contextualized muscular variations in the axillary region and their clinical relevance, we present an anatomical variation of this type, which is of interest for surgeons and anatomists considering its implications during surgery or dissection of a cadaver.

\section{MATERIAL AND METHOD}

A unilaterally muscular variation is described, which was found during a routine dissection of an upper limb in a male cadaver, aged 56 years at the time of death. The limb had been fixed in $10 \%$-buffered formaldehyde and kept in refrigeration chamber at $4{ }^{\circ} \mathrm{C}$. There had been no prior surgical interventions in the area of study.

The anterior compartment of the right arm was dissected, first lifting the skin through a longitudinal incision extended between the base of the axilla and the upper third of the forearm, retracting the cutaneous tissue laterally and leaving the deep fascia intact. While dissecting the medial antebrachial cutaneous nerve and the basilic vein, a long, thin tendon that crossed deep into the vein was detected in the lower third of the arm. To identify this structure, the fascia was drawn back using the same technique as with the skin. The tendon was then tracked from distal to proximal, identifying a muscle located inside the axillary fossa. It was possible to determine the muscle's origin, insertion, vascularization, innervation, and anatomical relationships.

\section{RESULTS}

A thin flat muscle was found in the axillary fossa posterior to the pectoralis major muscle, which originated from three fascicles that according to their positions are the upper, middle and lower fascicles. The upper fascicle emerged from the anterior wall of the thorax as a thin muscular extension of the pectoral fascia and the anterior sheet of the clavipectoral fascia. From its origin, this fascicle was directed to the axillary fossa, joining in this trajectory with the middle fascicle emerging from the

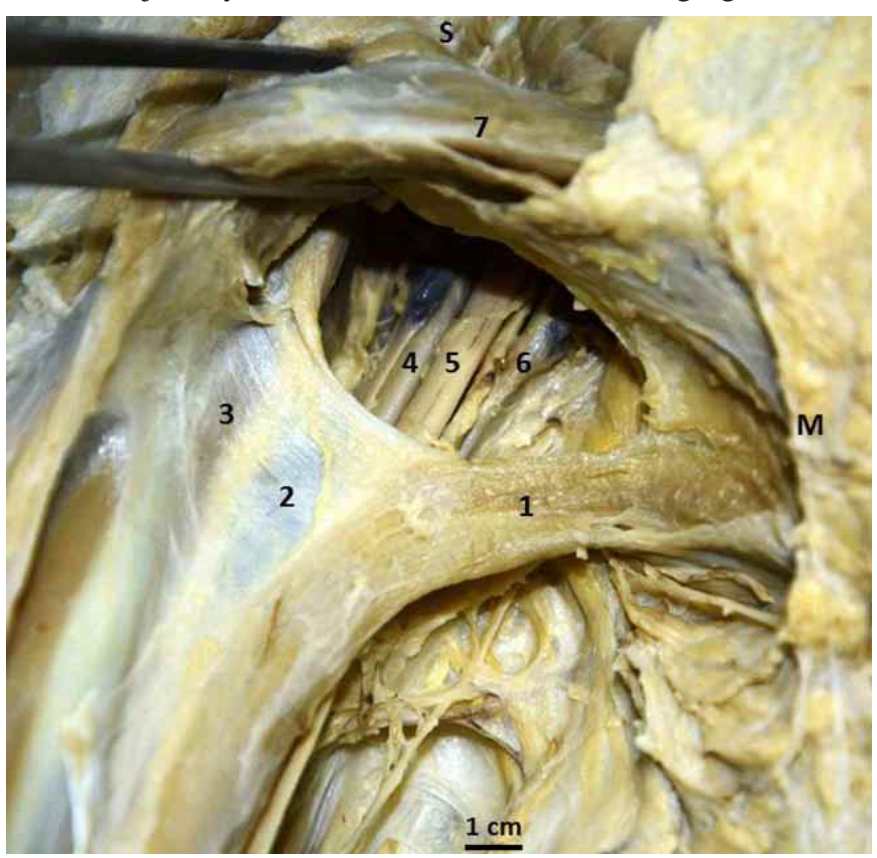

Fig. 1. Dissection of the axillary anterior wall and base. 1 . Dorsoepicondylar medial muscle; 2. Upper fascicle; 3. Middle fascicle; 4. Lower fascicle; 5. Pectoralis major muscle; 6. Median nerve; 7. Dorsoepicondylar medial tendon; 8. Basilic vein; S. Superior; M. Medial.
Fig. 2. Anterior view of the axilla, the anterior wall was raised to expose the axillary content. 1 . Dorsoepicondylar medial muscle; 2 . Brachial duct; 3. Coracobrachialis fascia; 4. Axillary artery; 5. Median nerve; 6. Axillary vein; 7. Pectoralis major muscle; S. Superior; M. Medial. 


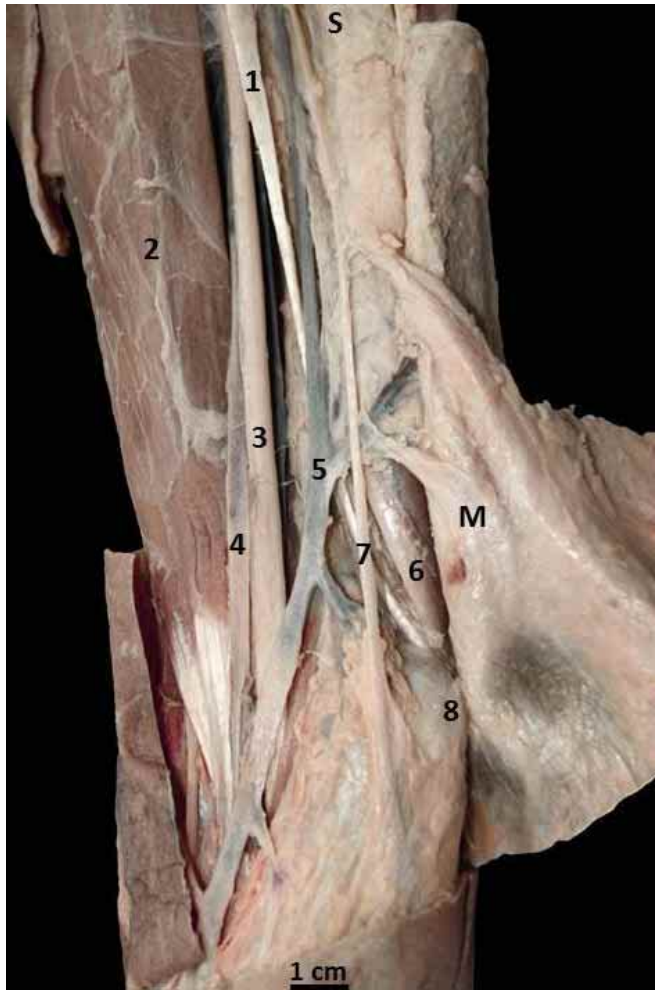

Fig. 3. Dissection of the lower third of the arm, elements related to the tendon of the dorsoepicondylar medial muscle are shown. 1. Dorsoepicondylar medial tendon; 2. Brachial biceps muscle; 3. Median nerve; 4. A. Brachial artery; 5. V. Basilic vein; 6. Ulnar nerve; 7. Medial antebrachial cutaneous nerve; 8 . Medial epicondyle; S. Superior; M. Medial. latissimus dorsi muscle, although clearly separated from it. The lower fascicle emerged from the latissimus dorsi muscle as an extension of its anterior fibers, which were separated from this muscle at the level of the axillary base, where the three aforementioned fascicles converge. This union resulted in a thin and curved muscular belly, with its concavity directed downwards, $120 \mathrm{~mm}$ long from the union of the three fascicles to the point where the tendon begins. The most voluminous portion of the muscular belly had a cross-sectional diameter of $15 \mathrm{~mm}$ and a thickness of $2 \mathrm{~mm}$ (Fig. 1).

Owing to its flat shape and its position in the frontal plane, it was possible to describe two edges at the carnous part of this muscle. The lower edge, in close relationship to the axillary fascia, continued distally towards the brachial fascia. In the other hand, a thin fascia extended laterally from the upper edge. This fascia was continuous with that of the coracobrachialis muscle and the short head of the biceps brachii, forming an arch of superior concavity that covered the vascular and nerve structures of the armpit and accompanying them in their brachial trajectory (Fig. 2).

A thin $150 \mathrm{~mm}$ long tendon located medially between the brachial muscles and the long head of the brachial triceps originated in the junction of the upper and middle thirds of the arm from the carnous portion (Fig. 1). In its trajectory in the middle third of the arm, this tendon crossed the ventral aspect of median nerve, which it accompanied along its medial margin. In the lower third, this tendon was transiting medially, taking relation with the deep aspect of the basilic vein and the medial antebrachial cutaneous nerve, applied to the medial head of the brachial triceps muscle. In this part, the tendon also related laterally to the ulnar nerve and the recurrent anterior ulnar vessels until its insertion into the medial epicondyle of the humerus (Fig. 3).

The innervation of the lower and middle fasciculus was by branches of the thoracodorsal nerve, while the innervation of the upper fascicle could
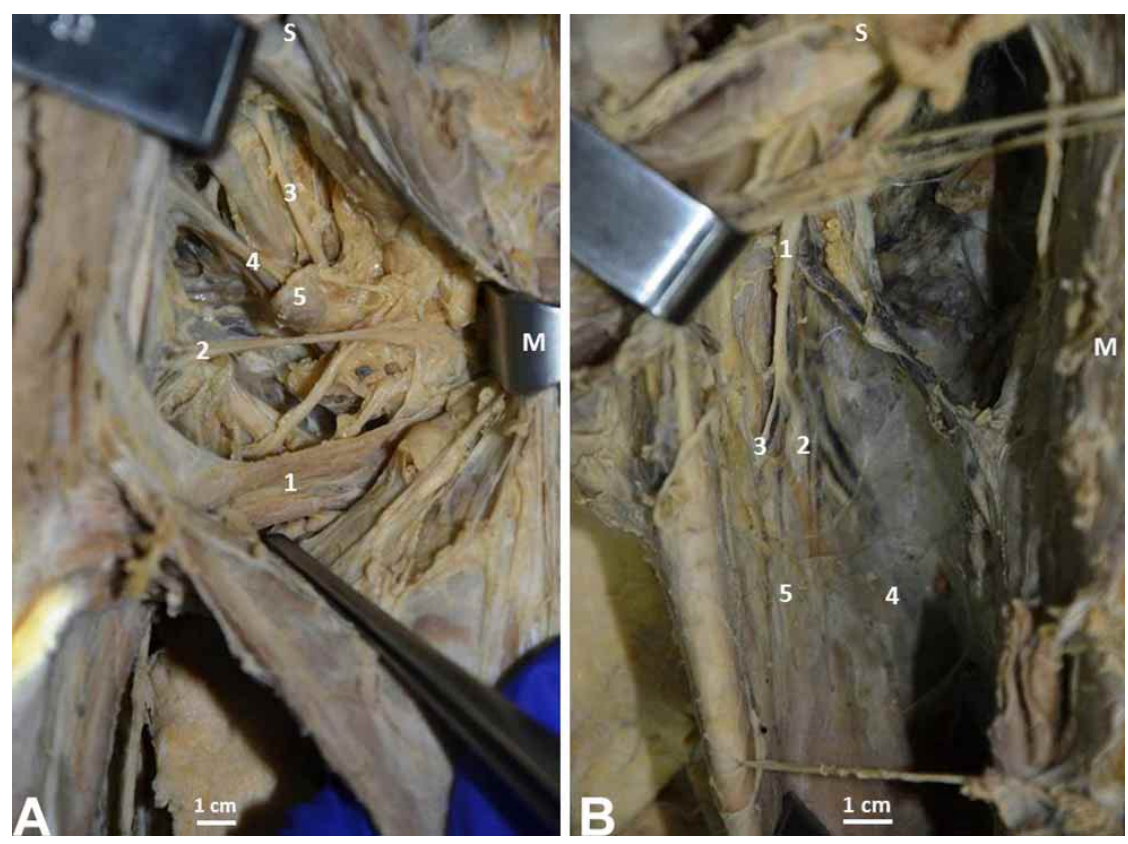

not be determined. The vascularization observed was double: thoracodorsal vessels to the lower and middle fasciculus, while at the level of the axilla branches from the axillary vessels were observed entering directly into the superior fasciculus.

Fig. 4. Vascularization and innervation of the dorsoepicondylar medial muscle. A. Anterior view of the axillary region. 1. Dorsoepicondylar medial muscle; 2 . Vessels of axillary origin; 3 . Thoracodorsal nerve; 4. Subscapular vessels; 5. Subscapular lymph node. B. View of the deep face of the latissimus dorsi muscle. 1. Thoracodorsal nerve; 2. Vessels and nerves of the lower fascicle; 3 . Vascular nerve branch of the middle fascicle; $4 \mathrm{M}$. Latissimus dorsi muscle; 5. Middle fascicle; S. Superior; M. Medial. 


\section{DISCUSSION}

Comparing the literature and ours findings, we can affirm that the muscle we found is the dorsoepicondylar medial muscle. Over the years, this muscle has had different names, such as "Duvernoy's dorsoepitrochlearis muscle", "Broca's large dorsal accessory", "Bischoff's latissimuscondileas" etc. (Testut, 1884), and recognized traditionally as the "dorsoepitrochlear muscle" it is now recognized by the scientific community as the dorsoepicondylar medial muscle, although this is not the official name under the International Anatomy Terminology (Comité Federal sobre Terminología Anatómica \& Sociedad Anatómica Española, 2001). This structure is a flattened muscle that is a supernumerary variant of latissimus dorsi muscle, which emerges from it in the vicinity of the intertubercular sulcus of the humerus and runs down the medial side of the arm until it reaches the medial epicondyle or the olecranon (Testut). This muscle is found in the majority of mammals. In humans, it is represented by a fibrous arch that joins the latissimus dorsi muscle with the long head of the brachial triceps at the lateral wall of the axilla, although it can also be presented in a carnous state (Testut \& Latarjet, 1967). This description concurs with that of Birmingham (1889), who also stressed that it should not be homologated with the fourth pectoral muscle because its insertion points and trajectory do not correspond. Goss (1973) described the dorsoepicondylar medial muscle as a fibrous and occasionally as a muscular band emerging from the inferior edge of the tendon of the latissimus dorsi muscle and extended along the brachial triceps muscle.

Among the possible muscular variations of the axillary region, the dorsoepicondylar medial muscle stands out because of its uncommonness, having been reported less than 30 times in the last 200 years (Loukas \& Tubbs, 2009). Our finding has an additional value because of the characteristics of the muscle, which is formed by the union of three muscular fascicles that converge in a common tendon, which according to Shah et al. (2014) is atypical. In fact, the fibrous form is far more common (Testut \& Latarjet; Goss), which makes our case something more exceptional; our finding is similar to the structure observed in other mammals. Besides, the dorsoepicondylar medial muscle is described in comparative anatomy as being common to all quadruped mammals (Leche, 1900, apud Haninek et al., 2009), in which it is in complete form, that is, detached from the lower anterior edge of the latissimus dorsi muscle near its insertion tendon, passing like an arch through the axilla and descending into the arm in the plane of the medial intermuscular septum, where it ends inserted in the medial epicondyle of the humerus (Haninec et al.).
The complete or incomplete development of the dorsoepicondylar medial muscle can be explained by the embryological development of the latissimus dorsi muscle, which can already be seen in a 15 to $16 \mathrm{~mm}$ human embryo. The latissimus dorsi muscle derives genetically from the same primordium muscle as the teres major, which originates as muscular band of cranial-caudal orientation found between the eleventh rib and the adjacent vertebra, and extending to the humerus, the latter being its primitive point of insertion (Orts Llorca, 1970; Haninec et al.).

Subsequently, these insertions expand fan-like, increasing the insertion surface. In the course of its development, the arch of the muscular primordium that crosses the axilla and continues as the medial intermuscular septum of the arm is interrupted and disappears, presumably by apoptosis, its remnants constituting the dorsoepicondylar medial muscle in its different types of presentation (Shah $e t$ $a l$. ), such as the chondroepitrochlear, chondrohumeral and pectorodorsal muscles (Loukas \& Tubbs). The dorsoepicondylar medial muscle described in this case includes anatomical origins that involve the latissimus dorsi and the pectoralis major muscles, the dorsi-pecturum-medial epicondylar being the most accurate designation since it was the latissimus dorsi muscle that contributes most in its formation.

The innervation of the middle and lower fascicles of this muscle depended of branches of the thoracodorsal nerve (Fig. 4), as other authors have suggested (Haninec et al.; Shah et al.). However, it was not possible to identify the origin of the innervation of the upper fascicle, which if it was by neighborhood, it could be given by a muscular branch from the intercostal nerves. Functionally, the dorsoepicondylar medial muscle could act as a weak adductor of the arm given its insertion points and the direction of its muscular fibers.

There is little anatomical, imagining and symptomological information about the dorsoepicondylar medial muscle in the clinical field, which could erroneously be interpreted as a result of the lack of clinical manifestations. Some authors have noted that the presence of this muscle can cause functional limitations on the glenohumeral joint and/or compression of the neurovascular elements of the axilla. Compression of nerves in the upper arm owing to muscular variations or hypertrophy are common and they generate symptomologies that confound examiners (Salgado et al., 2012). With respect to this, Natsis et al. (2012) reported the case in which physical examination revealed a limitation in the mobility of the shoulder and a sensation of tension in abduction. The diagnosis based on magnetic resonance confirmed the presence of the dorsoepicondylar medial 
muscle as the cause of the limitation. Spinner et al. (1991) made a similar observation, stating that the presence of this muscle resulted in numbness in the small and ring fingers, especially when extending and raising the humerus, a symptomology that disappeared when the dorsoepicondylar medial muscle was sectioned. In relation to this type of manifestation, Haninec et al. documented two cases of neurological compression and paresthesia caused by the presence of the dorsoepicondylar medial muscle. In one case, the patient underwent rehabilitation for a year to treat painful symptomology in the scapular region, but without positive results. Electromyography revealed atrophy of the serratus anterior because of compression of the long thoracic nerve owing to the presence of the dorsoepicondylar medial muscle. In another case, a patient complained of paresthesia and pain in the medial region of the forearm and in the hypothenar region. The patient was treated for carpal tunnel compression without any clinical improvement. Then, it was suspected an impingement of the ulnar nerve and the antebrachial cutaneous nerve at the level of the axilla, but the cause of the compression was found to be the dorsoepicondylar medial muscle. It can be inferred from these reports that the spectrum of clinical manifestation of the presence of the dorsoepicondylar medial muscle can range from the asymptomatic to muscular paresthesia and atrophy, where a timely physical examination and a basis of knowledge of these anatomical variations are relevant to correct diagnosis and adequate treatment.

Knowledge of this type of variation enriches clinical and surgical practice, highlighting the importance of anatomy in clinical practice. We hope this work will contribute to the knowledge of axillary anatomical variations and improve the surgical performance of doctors specializing in attending patients with pathologies located in this region.

\section{ACKNOWLEDGEMENTS}

We would like to thank the people that with great generosity donate their bodies to the science, contributing to the development of new professionals.

FARFÁN, C. E.; INZUNZA, H. O.; ECHEVERRÍA, M. M. \& INOSTROZA, R. V. El músculo dorsoepicondilar medial. Una variación anatómica clínicamente relevante. Int. J. Morphol., 37(2):600-605, 2019.

RESUMEN: Las variaciones anatómicas son frecuentes en la región axilar, sin embargo no siempre figuran en los textos modernos de anatomía humana, existiendo un potencial riesgo de error diagnóstico y quirúrgico para quienes no las consideren. Se presenta una variación anatómica en la región axilar de tipo muscular que potencialmente puede generar manifestaciones clínicas o inducir iatrogenias durante un abordaje quirúrgico. Disección de rutina de miembro superior realizada en un cadáver adulto de sexo masculino. Se detectó un músculo atípico en la región axilar ubicado en la base de la axila derecha, compuesto por 3 fascículos musculares que dieron origen a un vientre muscular común. Los 3 fascículos, se unían en la base de la axila, formando un músculo delgado y plano de $120 \mathrm{~mm}$ longitud desde la unión de los fascículos hasta su tendón, con un diámetro transversal de $15 \mathrm{~mm}$ y un grosor de $2 \mathrm{~mm}$. El vientre común del músculo establecía una relación posterior con los elementos neurovasculares de la fosa axilar y los cubría parcialmente. A nivel de la unión de los tercios superior y medio del brazo, desde el vientre muscular común se originaba un delgado tendón de $150 \mathrm{~mm}$ de longitud, que terminaba insertándose en el epicóndilo medial del húmero, relacionándose en su trayecto con los elementos musculares y neurovasculares del brazo. Conocer esta variación enriquece la capacidad diagnóstica y quirúrgica reduciendo la posibilidad de iatrogenia en la cirugía de las regiones axilar y braquial.

PALABRAS CLAVE: Músculo dorsoepicondilar medial; Variación anatómica; Anatomía clínica.

\section{REFERENCES}

Birmingham, A. Homology and innervation of the achselbogen and pectoralis quartus, and the nature of the lateral cutaneous nerve of the thorax. J. Anat. Physiol., 23(Pt. 2):206-23, 1889.

Comité Federal sobre Terminología Anatómica \& Sociedad Anatómica Española. Terminologia Anatomica. Terminología Anatómica Internacional. Madrid, Médica Panamericana, 2001.

del Sol, M. \& Olave, E. Elevator muscle of the tendon of latissimus dorsi muscle. Clin. Anat., 18(2):112-4, 2005.

del Sol, M. \& Vásquez, B. Anatomical and clinical considerations of the pectoralis tertius muscle in man. Int. J. Morphol., 27(3):715-8, 2009

Goss, C. (Ed.). Anatomy of the Human Body. $29^{\text {th }}$ ed. Filadelfia, Lea \& Febiger, 1973.

Haninec, P.; Tomás, R.; Kaiser, R. \& Cihák, R. Development and clinical significance of the musculus dorsoepitrochlearis in men. Clin. Anat., 22(4):481-8, 2009

Inzunza, O.; Marín, A.; Pino, F.; Navarrete, C. \& Vargas, A. Panniculus carnosus, vestigial remanents in the axillary region. Int. J. Morphol., 26(4):841-4, 2008

Kutiyanawala, M. A.; Stotter, A. \& Windle, R. Anatomical variants during axillary dissection. Br. J. Surg., 85(3):393-4, 1998.

Leche, W. Mammalia, Musculatur. Bronn's Klassen und Ordnungen des Thier-Reichs. Bd VI. Leipzig, Abt. V. C. F. Wintersche Verlagshandlung, 1900 Apud Haninec, P.; Tomás, R.; Kaiser, R. \& Cihák, R. Development and clinical significance of the musculus dorsoepitrochlearis in men. Clin. Anat., 22(4):481-8, 2009.

Loukas, M. \& Tubbs, R. S. Musculus dorsoepitrochlearis. Clin. Anat., 22(6):782, 2009.

Natsis, K.; Totlis, T.; Vlasis, K.; Sofidis, G.; Lazaridis, N. \& Tsitouridis, I. Dorsoepitrochlearis muscle: an unknown cause of shoulder motion limitation and axilla deformity. J. Orthop. Sci., 17(2):1868, 2012. 
Ortiz, J. I.; Ramirez, V. F.; Petrosino, P.; Milano, M.; Arenas, A. \& Castillo, V. Langers's axillary arch (axillopectoral muscle): inusual supernumerary variant's latissimus dorsi. Three cases report. Int. J. Morphol., 27(4):1209-12, 2009.

Orts Llorca, F. Anatomía Humana. Tomo Primero. Aparato Locomotor. Tronco. Cabeza y Cuello. $4^{\text {th }}$ ed. Barcelona, Científico-Médica, 1970.

Salgado, G.; Cantín, M.; Inzunza, O.; Muñoz, A.; Saez, J. \& Macuer, M. Bilateral reversed palmaris longus muscle: a rare anatomical variation. Folia Morphol. (Warsz), 71(1):52-5, 2012.

Sawada, M.; Ishibashi, Y.; Suzuki, T. \& Chiba, S. Case reports on the pectoralis quartus and the pectoralis intermedius muscles. Kaibogaku Zasshi, 66(2):99-105, 1991.

Shah, I. P.; Yadav, A.; Mehta, R. \& Thatte, M. Variation of the latissimus dorsi. Indian J. Plast. Surg., 47(3):453-5, 2014.

Spinner, R. J.; Carmichael, S. W. \& Spinner, M. Infraclavicular ulnar nerve entrapment due to a chondroepitrochlearis muscle. J. Hand Surg. Br., 16(3):315-7, 1991.

Standring, S. Gray's Anatomy. The Anatomical Basis of Clinical Practice. $41^{\text {st }}$ ed. Philadelphia, Elsevier, 2016.

Testut, L. \& Latarjet, A. Anatomía Humana. Tomo Primero. OsteologíaArtrología-Miología. $9^{\text {th }}$ ed. Barcelona, Salvat, 1967.

Testut, L. Anomalies Musculaires Chez L'Homme. Paris, Masson, 1884.
Corresponding author:

Emilio Farfán Cabello M.Sc. Klgo.

Profesor Asistente

Departamento de Anatomía

Facultad de Medicina

Pontificia Universidad Católica de Chile

Libertador Bernardo O'Higgins 340

Edificio Pregrado de Medicina $8^{\circ}$ piso

Santiago

CHILE

Email: efarfan@med.puc.cl

Received: 04-12-2018

Accepted: 28-01-2019 